\title{
EFFECT OF UNDERFEEDING, HEMIGONADECTOMY, SEX AND CYPROTERONE ACETATE ON SERUM FSH LEVELS IN IMMATURE RATS
}

\author{
SHEILA F. STEWART, SUSAN KOPIA AND D. L. GAWLAK \\ Warner-Lambert Research Institute, Morris Plains, New Fersey 07950, U.S.A.
}

(Received 13th February 1975)

Dietary regimens have been shown to influence the secretion of gonadotrophins (Mulinos \& Pomerantz, 1940; Leathem, 1958; Srebnik \& Nelson, 1963), the changes occurring as the result of decreased hypothalamic content of FSH-RF and LH-RF (Piacsek \& Meites, 1967) or FSH-RF activity (Negro-Vilar et al., 1971). Root \& Russ (1972) demonstrated that fasting reduced serum FSH levels in intact male rats whereas Howland (1971a) reported that no change occurred in fasted female rats. Root \& Russ (1972) and Ibrahim \& Howland (1972) found that castration increased serum FSH levels, but the release of FSH was inhibited in the females and increased in the males when they were also fasted. A similar increase in FSH secretion in both sexes has been shown many times (Benson et al., 1969; Ibrahim \& Howland, 1972; Howland \& Skinner, 1973; Stewart et al., 1973; Ramirez \& Sawyer, 1974) to occur after unilateral gonadectomy. Restriction of food to hemicastrated male rats resulted in increased levels of serum FSH compared with those of fully fed controls (Stewart et al., 1973). The present study was undertaken to determine (a) if the FSH response to underfeeding in the female was similar to that of the male, and (b) if the administration of cyproterone acetate, an anti-androgenic compound, to male rats would indicate what part androgens played in FSH release, since cyproterone acetate will block "androgen-sensitive CNS-receptors that regulate FSH secretions" (Von Berswordt-Wallrabe \& Neumann, 1967; Sar \& Stumpf, 1973).

Three separate experiments were carried out, two in which immature male and female rats of the Sprague-Dawley strain were untreated and one in which immature male rats were subcutaneously injected with $0.5 \mathrm{mg}$ cyproterone acetate daily for 14 days. In all the experiments the animals were either intact or hemicastrated and fully fed, or intact and hemicastrated and subjected to an intake of food which was $50 \%$ of the amount consumed by the fully fed control rats. Unilateral gonadectomy was performed on the females at 26 days of age and on the males at 21 days of age. The dietary regimen was begun $24 \mathrm{hr}$ later and the experiments lasted 14 days; the rats were decapitated on the 15th day between 09.30 and 11.30 hours. The blood was collected in tubes, placed in crushed ice and the serum was separated and frozen until used to determine the 


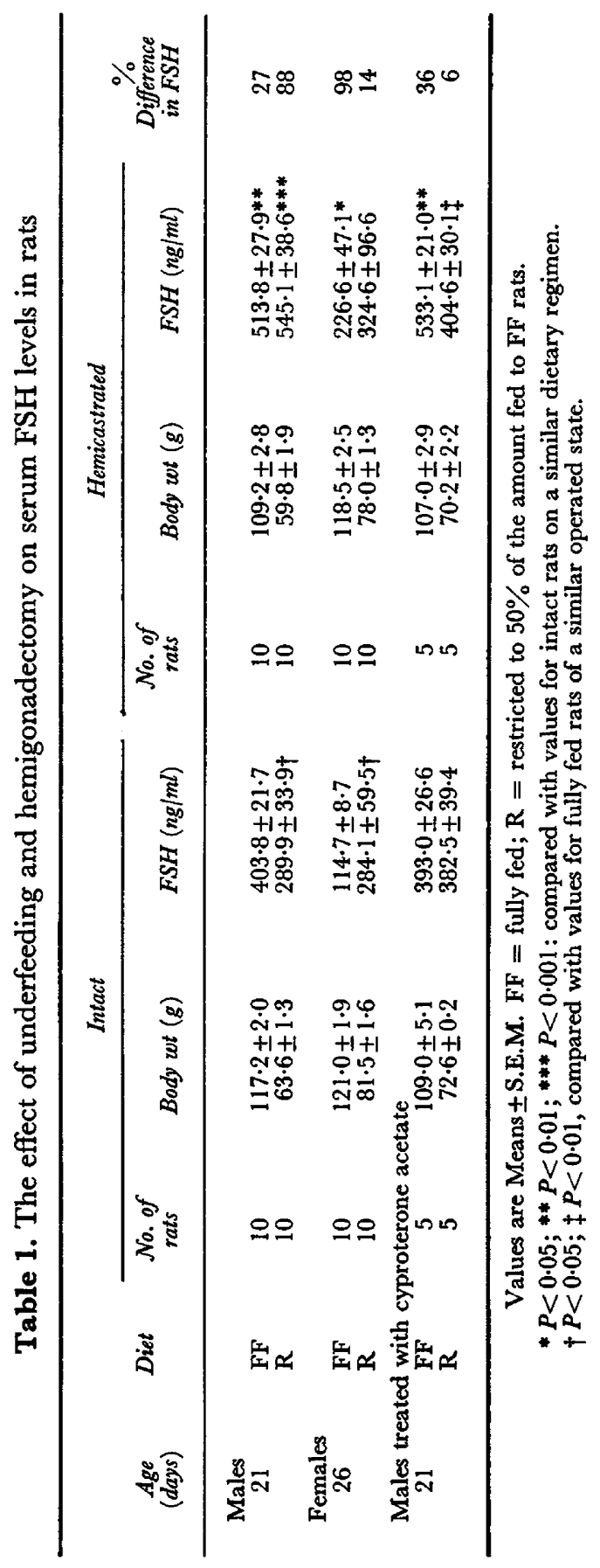


FSH levels by radioimmunoassay (Greenwood et al., 1963; Berson et al., 1964) with NIAMD standard FSH-RP1 and NIAMD-anti-rat-FSH serum-3. Females were subjected to surgery when 26 days old, 5 days later than males, since compensatory hypertrophy did not occur consistently after unilateral ovariectomy at Day 21 . The males, on the other hand, showed a greater gonadal response at 21 days than at 26 days; thus, the rats of different ages were considered more comparable in their response to hemigonadectomy than when they were at the same age.

Serum FSH levels fell significantly $(P<0 \cdot 05)$ in the intact male rats fed a restricted diet (Table 1), but the hemicastrated rats responded to underfeeding with a slight but statistically insignificant rise in serum FSH. In previous similar experiments (Stewart et al., 1973) the statistical significance was reversed, but the results of subsequent experiments were similar to those in this report. The reversal could have been due to age differences since the rats in the early experiments were chosen according to weight and not age. Thus, the tendency is for underfeeding to decrease serum FSH levels in intact male rats and either increase or not change serum FSH in hemicastrated male rats.

Hemicastration significantly increased the serum FSH levels of rats in both dietary groups above those of the intact controls (Table 1).

The intact immature female rats responded differently from the males to dietary restriction; FSH levels increased rather than decreased, but as in the male, underfeeding had no significant effect in hemiovariectomized females. When Howland (1971a) reduced the feed intake of intact female rats by $50 \%$, no difference in serum FSH levels ensued, but his animals were 2 to 5 times older than the 4- to 6-week-old intact animals in the present experiments. We have found that after 40 days of age, the variation in FSH levels occurring within a group was too great to allow identification of the subtle basic changes that occur with diet. In mature rats, Ibrahim \& Howland (1972) found that after ovariectomy fasting had no significant effect on the FSH levels, a finding similar to that for the immature hemicastrated animals in the present study, except that theirvalues tended to be lower than in fully fed rats, and ours slightly higher in the hemicastrated animals. Once again, one of the principal differences was the age of the animals.

Hemiovariectomy of fully fed immature rats was followed by increased serum FSH levels, but underfeeding caused no change.

Administration of cyproterone acetate to immature male rats abolished the inhibition of FSH secretion in intact rats and the augmented response of FSH to hemicastration associated with underfeeding of untreated male rats.

These results indicate that in intact rats fed a restricted diet serum FSH levels were decreased in males and increased in females. The response to underfeeding in the female differed from that to fasting observed by Ibrahim \& Howland (1972), but the response of males was similar to the observations of Root \& Russ (1972). The response of males was presumably the result of a depletion of FSH-RF (Negro-Vilar et al., 1971), but when cyproterone acetate was administered to the underfed male rat the release of FSH increased, suggesting that the inhibition of FSH in the untreated male had been the result of androgen feedback on the hypothalamic FSH-RF. Underfeeding of 
male rats, but not females, after hemicastration augmented the compensatory rise in FSH levels. The compensatory rise of FSH was abolished by administration of cyproterone acetate, suggesting that androgens in the untreated rat had been required for the augmented release of FSH. By inference, it appears that underfeeding sensitized the hypothalamic response to steroids (androgens), supporting the suggestions of Howland (1971b) after steroid administration to underfed female rats. The present data also indicate that the sensitivity to androgens was different in the intact rat, in which androgens inhibited FSH, from that in the hemicastrated animal in which FSH release was increased by androgens, i.e. the hypothalamic sensitivity to steroids caused by underfeeding was reversed by hemicastration in the immature male rat.

The authors are grateful for the purified rat FSH (NIAMD-Rat-FSH-I-1) and rabbit-anti-Rat-FSH-serum-3 and NIAMD-Rat-FSH-RP1 provided by the National Institute of Arthritis and Metabolic Diseases, Rat Pituitary Hormone Program.

\section{REFERENCES}

Benson, B., Sorrentino, S. \& Evans, J.S. (1969) Increase in serum FSH following unilateral ovariectomy. Endocrinology 84, 369-374.

Berson, S.A., Yallow, R.S., Glick, S.M. \& Roth, J. (1964) Immunoassay of protein and peptide hormones. Metabolism 13, 1135-1153.

Greenwood, F.C., Hunter, W.M. \& Glover, J.S. (1963) The preparation of I $^{131}$ labelled human growth hormone of high specific radioactivity. Biochem. J., 89, 114-123.

HowLAND, B.E. (1971a) Gonadotrophin levels in female rats subjected to restricted feed intake. 7. Reprod. Fert. 27, 467-470.

HowLAND, B.E. (1971b) Castration hypersecretion of luteinizing hormone but lack of ovarian compensatory hypertrophy in underfed rats. Experientia 27, 1484-1485.

HowLAND, B.E. \& SxinNER, K.R. (1973) Effect of hemi-ovariectomy on serum FSH and LH levels during the oestrous cycle in the rat. F. Reprod. Fert. 32, 501-503.

IBRAHIM, E.A. \& HowLAND, B.E. (1972) Effect of starvation on pituitary and serum follicle-stimulating hormone and luteinizing hormone following ovariectomy in the rat. Can. F. Physiol. Pharmac. 50, 768-773.

Leathem, J.H. (1958) Hormones and protein nutrition. Recent Prog. Horm. Res. 14, 141-176.

Mulinos, M.G. \& Pomerantz, L. (1940) Pseudohypophysectomy: a condition resembling hypophysectomy produced by malnutrition. F. Nutr. 19, 493-504.

Negro-Vilar, A., Dickerman, E. \& Meites, J. (1971) Effects of starvation on hypothalamic FSH-RF and pituitary FSH in male rats. Endocrinology 88, 1246-1249.

Piacsek, B.E. \& Meites, J. (1967) Reinitiation of gonadotropin release in underfed rats by constant light or epinephrine. Endocrinology 81, 535-541.

Ramirez, V.D. \& Sawyer, C.H. (1974) A sex difference in the rat pituitary FSH response to unilateral gonadectomy as revealed in plasma radioimmunoassay. Endocrinology 94, 475-482.

Root, A.W. \& Russ, R.D. (1972) Short-term effects of castration and starvation upon pituitary and serum levels of luteinizing hormone and follicle stimulating hormone in male rats. Acta endocr., Copenh. 70, 665-675.

SAR, M. \& STUMPF, W.E. (1973) Effects of progesterone or cyproterone acetate on androgen uptake in the brain, pituitary and peripheral tissues. Proc. Soc. exp. Biol. Med. 144, 26-29.

SREBNIK, H.H. \& Nelson, M.M. (1963) Influence of diet on the gonadotrophins of the anterior pituitary gland. In Proc. 6th Int. Congr. Nutr., pp. 375-386. Eds C. F. Mills \& R. Passmore. Livingston, Edinburgh.

Stewart, S.F., Gawlak, D. \& Kopia, S. (1973) The effect of caloric restriction on testicular hypertrophy following hemicastration in the rat. $\mathcal{F}$. Reprod. Fert. 34, 159-163.

Von BERSWORdT-WALlrabe, R. \& Neumann, F. (1967) Influence of a testosterone antagonist (cyproterone) on pituitary and serum FSH-content in juvenile male rats. Neuroendocrinology 2, 107-112. 